\title{
A LIBERDADE DE ENSINO E O MOVIMENTO ESCOLA SEM PARTIDO
}

Cássia Regina Dias Pereira ${ }^{\mathrm{i}} \oplus 0000-0003-1572-7002$

Universidade Estadual do Paraná - UNESPAR/Paranavaí

Thamiris Dias Vasconcelos ${ }^{\mathrm{ii}} ₫ 0000-0001-9377-8361$

Universidade Estadual do Paraná - UNESPAR/Paranavaí

RESUMO: Esta pesquisa é um estudo de revisão bibliográfica que analisa qualitativamente a proposta do programa Escola Sem Partido - ESP, seu embasamento legal e as implicações de suas diretrizes para o trabalho do professor em sala de aula. O movimento Escola Sem Partido é um programa que visa alterar a legislação educacional, tornando obrigatória a afixação nas salas de aula e sala dos professores de cartazes contendo seis deveres do professor ao desenvolver seu trabalho pedagógico. $\mathrm{O}$ programa defende ainda o direito dos alunos de filmarem as aulas, podendo o professor responder criminalmente pelo conteúdo dessas filmagens. Percebendo o avanço de ideais conservadores (até autoritários) em nossa sociedade, a presente pesquisa tem o objetivo de identificar o currículo oculto do programa Escola Sem Partido, analisando as vertentes políticas partidárias adjacentes ao mesmo, a falta de embasamento teórico que legitime a existência do ESP e no que significaria para o trabalho docente a implementação do programa na legislação educacional.

PALAVRAS-CHAVE: Programa Escola Sem Partido. Trabalho Docente. Ideologia.

\section{FREEDOM TO TEACH AND THE SCHOOL MOVEMENT WITHOUT PARTY}

ABSTRACT: This research is a bibliographic review study that qualitatively analyzes the proposal of the Escola Sem Partido - ESP program, its legal basis and the implications of its guidelines for the teacher's work in the classroom. The Escola Sem Partido movement is a program that aims to change the educational legislation, making it mandatory to display posters in the classrooms and teachers' room containing six duties of the teacher when developing his pedagogical work. The program also defends the right of students to film the classes, and the teacher can criminally answer for the content of these films. Realizing the advancement of conservative (even authoritarian) ideals in our society, the present research has the objective of identifying the hidden curriculum of the Escola Sem Partido program, analyzing the political party aspects adjacent to it, the lack of theoretical foundation that legitimizes the existence of ESP and what the implementation of the program in educational legislation would mean for teaching work. 
KEYWORDS: School Without Party Program. Teaching Work. Ideology. 
DOI 10.33872/revcontrad.vlnl.e002 | v. 1, n. 1 | Jan./Jun. 2020

\section{Introdução}

A educação nacional é alvo de críticas, sugestões, palpites da sociedade em geral, especialmente daqueles sem conhecimento ou formação específica para tratar sobre a mesma. A pesquisa visou investigar de que maneira o partidarismo subjacente ao programa escola sem partido (ESP) (discutido no Brasil entre os anos de 2014 a 2019 que busca alterar a legislação educacional) foi planejado e qual sua possível intervenção no trabalho dos docentes em sala de aula?

Os ataques contra as instituições de ensino surgem, sobretudo, quando estes estão relacionados à luta dos professores por melhores salários e condições de trabalho e até mesmo a luta pelos direitos dos próprios alunos, como quando houve as paralisações e ocupações das escolas (este último, pelos alunos secundaristas e universitários em 2016, como resposta à reforma do ensino médio).

Por meio de movimentos de mobilização, greves e paralisações os profissionais da educação exigem seus direitos e cobram das autoridades providências. Tais manifestações acabam por interromper as aulas, o que acarreta consequências como, atraso no cumprimento do ano letivo, dificuldade das famílias em remanejar a guarda dos filhos nos horários em que estes estariam em aula, os profissionais da educação ficam expostos a vários tipos de censura e retaliação, entre outros desconfortos que a situação de paralisação das atividades traz consigo.

Estes argumentos acabam desvalorizando a luta dos professores, pois torna cômodo a sociedade menosprezar a luta desses trabalhadores por seus direitos, ao invés de ajudá-los, fomentando a pressão sobre os responsáveis pela administração da educação nacional. Essa desvalorização do trabalho docente, por esses e por outros diversos motivos são explorados em momentos oportunos por determinadas vertentes da sociedade e dos poderes constituídos.

Sabe-se que a educação é o meio pelo qual o indivíduo se liberta de suas amarras e ignorância, é o meio pelo qual ele se torna autônomo, e isso se dá desde a alfabetização quando a criança passa a dominar a leitura e a escrita. É por meio da educação que o cidadão conhece seus direitos e deveres e passa a enxergar-se como um ser atuante, pensante, capaz de decidir seus caminhos. $\mathrm{O}$ indivíduo se reconhece por meio dela como um ser ativo e não mais passivo na sociedade.

O poder de autonomia produzido pela educação pode ser considerado libertador para alguns e "ideologizador" para outros. Sobre esta última, a ideia de educação ideológica nasceu 
DOI 10.33872/revcontrad.vlnl.e002 | v. 1, n. 1 | Jan./Jun. 2020

o Programa Escola Sem Partido (ESP), idealizado e a coordenado por Miguel Francisco Urbano Nagib. É advogado e idealizador do texto que originou diversos projetos de lei homônimos com o objetivo de limitar a ideologia de esquerda no ambiente acadêmico. É procurador do Estado de São Paulo em Brasília desde 1985 e foi assessor de ministro do Supremo Tribunal Federal de 1994 a 2002.

O movimento Escola Sem Partido (ESP) surgiu em 2004, segundo Nagib, a ideia de criar o movimento surgiu após sua filha chegar da escola dizendo que o professor de História havia feito uma comparação entre Che Guevara, um dos líderes da revolução cubana, e São Francisco de Assis, um dos Santos da igreja Católica. Na ocasião, o professor tratava sobre as pessoas que abriram mão de tudo para dedicar-se exclusivamente a uma ideologia, seja ela política como foi o caso de Che Guevara, seja ela religiosa, como fez São Francisco de Assis (EL PAÍS, 2016).

O Programa Escola Sem Partido tem como principal objetivo acabar com a suposta doutrinação política partidária praticada pelos professores dentro das salas de aula. O ESP expõe em seu website com uma oratória carregada de neutralidade ideológica (pelo menos em suas páginas iniciais, pois, navegando pelo site, há disponível alguns artigos relacionados às suas propostas, onde se deixa claro e através de uma linguagem vulgarizada que a doutrinação a ser combatida dentro das salas de aula é a doutrinação "esquerdista") e em seu artigo $5^{\circ}$ do anteprojeto que busca implementar o ESP na LDB n. 9394/1996, que deveriam ser afixados dentro das salas de aula e salas dos professores um cartaz que traz seis tópicos contendo os deveres dos professores ao realizar seu trabalho pedagógico.

Além disso, traz em seu artigo $7^{\circ}$ do anteprojeto supracitado a necessidade das escolas disponibilizarem ou permitirem que os alunos façam filmagens das aulas. Segundo Nagib, se não há doutrinação os professores não precisam temer que os alunos tenham acesso ao cartaz que os esclarece sobre os deveres do docente em sala de aula, e que as filmagens seriam uma forma do aluno ter acesso ao conteúdo já ministrado pelo professor, e ainda garantiria aos pais o acompanhamento da qualidade do ensino ofertado a seus filhos (CÂMARA DOS DEPUTADOS, Projeto de Lei n. ${ }^{\circ}$ 867/2015).

Com relação ao cartaz que trata dos deveres dos professores, este se resume em dizer que o professor não se aproveitará da audiência obrigatória do aluno em sala de aula para expor seus próprios interesses, opiniões, preferências ideológicas, religiosas, morais, políticas entre outras; o professor deverá apresentar de forma justa as questões políticas, socioculturais e econômicas, levando em consideração as principais versões, teorias, opiniões e perspectivas 
DOI 10.33872/revcontrad.vlnl.e002 | v. 1, n. 1 | Jan./Jun. 2020

recorrentes ao assunto; o professor se atentará ainda, em levar em consideração o direito dos pais dos alunos a que seus filhos recebam uma educação moral e religiosa de acordo com suas próprias convicções.

O ESP, no entanto, não deixa claro quais são os parâmetros que delimitam o ensinar, o orientar, o situar os processos históricos, culturais, econômicos, do que se pode considerar doutrinação. Nicolazzi (2016) diz que no atual cenário busca-se projetar o espaço familiar, o âmbito privado, sobre as questões da sociedade, onde deve prevalecer a dimensão pública como condição fundamental para as discussões sobre o bem comum e sobre a justiça social. Para o autor, tais projetos almejam um esvaziamento da dimensão pública do ensino, almejam a despolitização da prática educacional. "Conhecer é um ato social, não simplesmente uma faculdade biológica, ele pode e deve ser apartidário, mas jamais será "neutro" (NICOLAZZI, 2016, p. 84).

Não é possível uma efetiva educação sem a dimensão, que acontece através do livre diálogo entre professor e aluno e da liberdade de atuação do professor em sala de aula.

\section{Apontamentos iniciais}

Apesar do programa Escola Sem Partido (ESP) ter surgido no início dos anos 2000, foi a partir do ano de 2014 que este passou a ter maior visibilidade. Não é à toa que desde esse mesmo período o Brasil passou a contar com um crescente avanço dos movimentos conservadores.

O Brasil esteve sob o governo do Partido dos Trabalhadores por quatorze anos, o partido identificado como centro-esquerda foi destituído do poder através de um processo de impeachment que acusava a então presidente Dilma Rousseff de ter praticado "pedaladas fiscais". Durante o processo, em 2016, o país que se encontrava polarizado desde as eleições em 2014 acabou por dividir-se ainda mais, entre os que acreditavam que o impeachment na verdade fora um golpe de Estado contra a então presidente da república e os que apoiavam o resultado do processo veementemente.

Neste cenário caótico, onde a polaridade - direita/esquerda - acirrou-se a níveis exorbitantes em todas as áreas, a educação logo foi alvo da acirrada disputa, e é neste contexto que o ESP passa a tomar maior visibilidade.

O movimento como já explicitado, defende a implementação de um Projeto de Lei que busca proibir a doutrinação ideológica dentro das escolas, para tanto, os alunos teriam acesso 
DOI 10.33872/revcontrad.vlnl.e002 | v. 1, n. 1 | Jan./Jun. 2020

a um cartaz que seria afixado dentro das salas de aula contendo seis deveres dos professores, o anteprojeto desenvolvido pelo programa prevê ainda que os alunos ao se sentirem "lesados" pelo professor façam uma gravação da aula, podendo o professor responder criminalmente pelo material contido em tais filmagens.

O primeiro dever do professor de que trata o cartaz elaborado pelo ESP diz que, o professor não se aproveitará da audiência cativa dos alunos para promover os seus próprios interesses, opiniões, concepções ou preferências ideológicas, religiosas, morais, políticas e partidárias. Já no tópico quatro o cartaz diz que, ao tratar de questões políticas, socioculturais e econômicas, o professor apresentará aos alunos, de forma justa - isto é, com a mesma profundidade e seriedade -, as principais versões, teorias, opiniões e perspectivas concorrentes a respeito da matéria.

O cartaz traz os tópicos supracitados com uma linguagem neutra e desprovida de qualquer interesse que não seja de direito do aluno, no entanto, durante uma aula, o professor ao tratar de determinado momento histórico trará a análise social do mesmo período, ficando a cargo do aluno ter conhecimentos das principais teorias, versões, opiniões e perspectivas concorrentes que muitas vezes não cabem ser tratadas ali. Ou seja, uma filmagem fora de contexto, poderia acusar o professor de doutrinação pelo simples fato de ensinar o conteúdo que lhe cabe.

O tópico três diz que, o professor não fará propaganda político-partidária em sala de aula nem incitará seus alunos a participar de manifestações, atos públicos e passeatas. A necessidade de o professor ser apartidário enquanto desempenha seu trabalho em sala de aula é indiscutível (ainda que apartidário não queira dizer neutro), no entanto, a participação da população (seja a comunidade escolar, trabalhadores, sociedade civil organizada) em manifestações, atos públicos e passeatas é um direito constitucional garantido pelo artigo $5^{\circ}$ da Constituição Federal. É um direito característico de uma sociedade democrática. O ensino destinado a formação de cidadãos autônomos, ativos perante a sociedade, não só pode como deve passar pelo conhecimento de tais direitos.

Apesar da promoção de severas críticas ao pedagogo brasileiro Paulo Freire por parte do movimento, nos cabe aqui usar algumas de suas falas no que diz respeito à ideologia, neutralidade educacional, ética e diversidade de saberes e concepções.

Paulo Freire nos diz em seu livro Pedagogia da Autonomia que não há neutralidade na educação, isso porque para ele quem observa, quem analisa, o faz a partir de um ponto de vista já estabelecido e não de modo imparcial. Freire trabalhou com a alfabetização de jovens 
DOI 10.33872/revcontrad.vlnl.e002 | v. 1, n. 1 | Jan./Jun. 2020

e adultos em comunidades rurais o que o fez assumir o ponto de vista dessas pessoas ao fazer sua leitura de mundo.

O pedagogo ressalta que desde a escolha dos conteúdos a serem ensinados, desde a organização do Projeto Político Pedagógico escolar, onde são definidos o perfil dos alunos que se busca formar, tudo é movido por uma ideologia. Se a escola é democrática a constituição do PPP é feito em parceria com gestores, professores, profissionais e família, quando se trata de uma escola autoritária, são os ditos "especialistas" quem decide o que ensinar, de que forma ensinar, que alunos pretendem formar. Ou seja, tanto em um, quanto no outro, a organização escolar traz as ideologias e crenças daqueles que cumprem o papel de organizar as instituições de ensino.

O que Freire salienta é que independente de seu ponto de vista, de sua não neutralidade o que não pode ocorrer é não observar através de uma rigorosidade ética. $\mathrm{O}$ professor dentro da sala de aula traz consigo uma ideologia, parte de seu próprio ponto de vista, que julgamos ser incapaz de absoluta neutralidade, no entanto, a sua não neutralidade, torna-se insignificante quando o professor trabalha de forma ética, independentemente de suas crenças e ideologias. Nas palavras de Freire:

Na maneira como lidamos com os conteúdos que ensinamos, no modo como citamos autores de cuja obra discordamos ou cuja obra concordamos. Não podemos basear nossa crítica a um autor na leitura feita por cima de uma ou outra de suas obras. Pior ainda, tendo lido apenas a crítica de quem só leu a contracapa de um de seus livros. Posso não aceitar a concepção pedagógica deste ou daquela autora e devo inclusive expor aos alunos as razões por que me oponho a elas, mas, o que não posso, na minha crítica, é mentir. É dizer inverdades em torno deles. O preparo científico do professor ou da professora deve coincidir com sua retidão ética. É uma lástima qualquer descompasso entre àquela e esta. Formação científica, correção ética, respeito aos outros, coerência, capacidade de viver e de aprender com o diferente, não permitir que o nosso mal-estar pessoal ou a nossa antipatia com relação ao outro nos façam acusa-lo do que não fez são obrigações a cujo cumprimento devemos humilde, mas perseverantemente nos dedicar. É não só interessante, mas profundamente importante que os estudantes percebam as diferenças de compreensão dos faros, as posições as vezes antagônicas entre professores na apreciação dos problemas e no equacionamento de soluções. Mas é fundamental que percebam o respeito e a lealdade com que um professor analisa e critica as posturas dos outros (FREIRE, 1996, p. 10).

Ensinar para Freire exige respeito aos saberes dos educandos. $\mathrm{O}$ ensino precisa ser significativo ao aluno, ao desenvolver seu trabalho o professor deve relacionar aspectos de sua realidade com os conteúdos científicos, é necessário colocar o aluno no processo histórico 
DOI 10.33872/revcontrad.vlnl.e002 | v. 1, n. 1 | Jan./Jun. 2020

de produção da vida cotidiana. Relacionar em uma aula de geografia, por exemplo, porque da existência de um lixão em um bairro periférico e não em um bairro nobre, porque a atenção do governo a determinada área da cidade ou região do país ser maior que para outras, faz com que o educando entenda, se conscientize das relações políticas, que envolve sua realidade social.

Já sobre aqueles que discordam desse posicionamento, para eles à escola não cabe trabalhar essas relações sociais e esta deve restringir-se aos conhecimentos científicos (de modo a depositar no aluno os conhecimentos historicamente acumulados, educação bancária). Tal atitude já traz em sua essência uma opção política e ideológica, pois, há nessa postura o interesse de perpetuação do status quo, ou seja, busca-se formar alunos passivos, trabalhadores que se encaixarão na sociedade estática e estabelecida, sem nenhuma possibilidade de resistência ou transformação.

É claro que ao exigir neutralidade educacional, temos automaticamente uma nãoneutralidade. A escola precisa ser sobretudo, crítica e ética, mas se a condição de neutralidade for amordaçar a curiosidade do educando, calar os debates político-sociais, proibir o professor de fazer seus apontamentos e considerações, este já deixa de ser neutro e pior ainda, passa a ser autoritário. Paulo Freire declara ainda, que a educação por ser diretiva implica objetivos, sonhos, utopias, ideais, e que por isso mesmo, esta não pode ser neutra, pois é qualidade da prática educativa ser política. Ou seja, amordaçar os debates em sala de aula através de ameaças judiciais é negar à escola o direito e dever (inclusive) de cumprir seu papel de formar integralmente seus alunos.

\section{Constitucionalidade}

No que diz respeito a constitucionalidade do anteprojeto desenvolvido pelo ESP e em outros diversos Projetos de Lei inspirados no mesmo, temos o caso do estado de Alagoas, que em março de 2017 buscou implementar na educação estadual o Projeto de Lei n 7800/2016 (Projeto "Escola Livre".) O caso supracitado foi suspenso pelo ministro do Supremo Tribunal Federal (STF) Luís Roberto Barroso. Sobre esta lei o magistrado afirmou que:

A liberdade de ensinar é um mecanismo essencial para provocar o aluno e estimulá-lo a produzir seus próprios pontos de vista. Só pode ensinar a liberdade quem dispõe de liberdade. Só pode provocar o pensamento crítico, quem pode igualmente proferir um pensamento crítico. Para que a educação seja um instrumento de emancipação, é preciso ampliar o universo informacional e cultural do aluno, e não reduzi-lo, com a supressão de 
DOI 10.33872/revcontrad.vlnl.e002 | v. 1, n. 1 | Jan./Jun. 2020

conteúdos políticos ou filosóficos, a pretexto de ser o estudante um ser "vulnerável". O excesso de proteção não emancipa, o excesso de proteção infantiliza (ADI n. 5537, 2017, p. 24).

Na mesma Medida Cautelar na Ação Direta de Inconstitucionalidade 5.537 Alagoas, o ministro Luís Roberto Barroso traz ainda as considerações elencadas pelo Ministério da Educação sobre o referido projeto

O Ministério da Educação entende que, ao definir a neutralidade como um princípio educacional, o indigitado Projeto de Lei contradiz o princípio constitucional do pluralismo de ideias e concepções pedagógicas, uma vez que tal pluralidade efetiva-se somente mediante o reconhecimento da diversidade do pensamento, dos diferentes saberes e práticas. O cerceamento do exercício docente, portanto, fere a Constituição brasileira ao restringir o papel do professor, estabelecer a censura de determinados conteúdos e materiais didáticos, além de proibir o livre debate no ambiente escolar. Da mesma forma, esse cerceamento pedagógico impede o cumprimento do princípio constitucional que assegura aos estudantes a liberdade de aprender em um sistema educacional inclusivo (ADI n. 5537, 2017, p. 12).

O quinto direito do aluno e dever do professor explícito no cartaz diz que, o Professor deverá respeitar o direito dos pais dos alunos a que seus filhos recebam a educação religiosa e moral que esteja de acordo com suas próprias convicções. O que os idealizadores do ESP chamam de "direito" neste tópico está previsto no artigo 13 - Direito à Educação, do Protocolo Adicional à Convenção Americana sobre Direitos Humanos em Matéria de Direitos Econômicos, Sociais e Culturais "Protocolo de São Salvador" (Decreto no 3.321/1999), no entanto, o documento diz que os pais têm direito a escolherem a educação moral e religiosa que seus filhos irão receber desde que esta esteja de acordo com o pleno desenvolvimento da pessoa humana. Vale aqui destacar:

Art. 13. Direito à Educação [...]. 2. Os Estados-Partes neste Protocolo convêm em que a educação deverá orientar-se para o pleno desenvolvimento da personalidade humana e do sentido de sua dignidade, e deverá fortalecer o respeito pelos direitos humanos, pelo pluralismo ideológico, pelas liberdades fundamentais, pela justiça e pela paz. Convêm também em que a educação deve tornar todas as pessoas capazes de participar efetivamente de uma sociedade democrática e pluralista e de conseguir uma subsistência digna; bem como favorecer a compreensão, a tolerância e a amizade entre todas as nações e todos os grupos raciais, étnicos ou religiosos, e promover as atividades em prol da manutenção da paz. 3. Os Estados-Partes neste Protocolo reconhecem que, a fim de conseguir o pleno exercício do direito à educação: [...]. De acordo com a legislação interna dos Estados-Partes, os pais terão direito a escolher o tipo de educação que deverá ser ministrada aos seus filhos, desde que esteja de acordo com os princípios enunciados acima. Nenhuma das disposições do Protocolo poderá ser interpretada como 
DOI 10.33872/revcontrad.vlnl.e002 | v. 1, n. 1 | Jan./Jun. 2020

restrição da liberdade das pessoas e entidades de estabelecer e dirigir instituições de ensino, de acordo com a legislação dos Estados-Partes (BRASIL, Decreto n. 3.321, de 30 de dez. de 1999. Protocolo Adicional à Convenção Americana sobre Direitos Humanos em Matéria de Direitos Econômicos, Sociais e Culturais "Protocolo de São Salvador", São Salvador, nov./1988).

A escola é o espaço onde a criança passa a ter contato com o meio social que a cerca, isto é, quando ela passa a entender a diversidade que existe no mundo fora do seu círculo familiar, e isso é importante, é nesse sentido que a criança passa a desenvolver-se como cidadã, no convívio diário com pessoas diferentes, de religiões diferentes, costumes diferentes etc. Direcionar a educação escolar de modo a garantir que os alunos recebam apenas o ensino daquilo que é desejado pelas famílias é no mínimo inviabilizar o trabalho do professor, e descaracterizar o caráter laico e plural da escola.

Certa vez em uma aula que tratava sobre a Base Nacional Comum Curricular (BNCC) no curso de Pedagogia, discutíamos juntamente com a professora sobre a necessidade de nas aulas de Ensino Religioso os professores tratarem sobre todas as religiões, de modo que fique explícito a diversidade de religiões presentes na sociedade e suas particularidades. Uma das alunas da classe revelou que em virtude de sua crença, sentia-se incomodada por ensinarem sobre as diversas religiões e que cabia a família trabalhar tal conteúdo. Trazemos aqui o questionamento, até que ponto as suas concepções devem sobrepor-se ao ensino da diversidade social?

Ainda na Medida Cautelar na Ação Direta de Inconstitucionalidade 5.537 Alagoas (que trata do Projeto de Lei "Escola Livre" supracitado), o ministro do STF, Luís Roberto Barroso fez suas considerações acerca da necessidade de o professor levar em consideração que os alunos recebam a educação moral e religiosa pretendidas por seus pais, ele diz:

A contrariedade desse Projeto de Lei também está na afirmação de que a educação moral e prerrogativa dos pais, ignorando o Art. 205 da Constituição Federal que determina a educação dever do Estado e da família, em colaboração com a sociedade, sem distinguir competências exclusivas dos pais e da escola, não separando as diversas dimensões do processo educativo, que envolve apreensão de conhecimentos, a construção de valores e o desenvolvimento do pensamento crítico (ADI n. 5537, 2017, p. 13).

Além das convicções religiosas, o movimento ganha forte apoio por fazer grande apelo ao não tratamento de questões morais em sala de aula. Miguel (2016), traz em seu artigo - Da "doutrinação marxista” à "ideologia de gênero" - Escola Sem Partido e as leis da mordaça no parlamento brasileiro - que com o fortalecimento do discurso feminista e da luta 
DOI 10.33872/revcontrad.vlnl.e002 | v. 1, n. 1 | Jan./Jun. 2020

por direitos dos homossexuais as questões de gênero surgem como uma ameaça à família, e que as crianças seriam as mais vulneráveis à "ideologia de gênero", que vale ressaltar, vem tratar dos papeis sociais empregados a homens e mulheres levando em consideração sua condição biológica, e não, suas capacidades físicas, intelectuais etc. Para os ditos "conservadores" o trabalho de gênero com os alunos impediria a consolidação da identidade masculina ou feminina. Miguel (2016) diz:

A pretensa neutralidade projeta uma educação que é incapaz de intervir no mundo e, por isso, torna-se cúmplice das injustiças e das violências que nele ocorrem. A discussão sobre gênero é particularmente ilustrativa. A noção de que os papéis estereotipados de meninas e meninos, mulheres e homens, são naturais e obrigatórios leva, como consequência necessária, a reforçar as barreiras que isolam mulheres de determinados espaços sociais, a estigmatizar determinados comportamentos, a marcar como desviantes aqueles que não seguem a regra. A cultura do estupro, que deriva da ideia de que as mulheres não são seres capazes de autonomia, e as agressões a gays, lésbicas e travestis, vistos como "anormais" e, portanto, indignos de respeito, são dois dos efeitos decorrentes. Calculam-se mais de 5 mil feminicídios anuais no Brasil (Garcia et al., 2015); os assassinatos motivados pela homofobia ultrapassam a casa dos trezentos por ano (GGB, 2015). Impedir que gênero seja discutido na escola é impedir que se aja no sentido de reverter tal quadro. Uma escola "sem partido" é uma escola que toma o partido da injustiça e da opressão (MIGUEL, 2016, p. 615).

Conhecer e entender a necessidade de respeitar as pessoas independentemente de sua orientação sexual, religião, de seu gênero, cor, etnia e toda a diversidade presente na sociedade, não pode ser considerado uma ameaça a "família", a moral e aos bons costumes. Deve-se considerar uma ameaça ao estado laico e plural o preconceito e a falta de respeito a tudo que seja diferente daquilo que se acredita.

\section{Legitimação do programa Escola Sem Partido}

Sabendo de sua inconstitucionalidade e texto pouco embasado teoricamente, afinal, a intenção de manter o status quo, o cerceamento de liberdades individuais, a intenção de ignorar de forma massiva a pluralidade social, são práticas inadmissíveis em qualquer sociedade consideravelmente desenvolvida. O ESP usa de uma estratégia chamada "Mecanismo da denúncia" que segundo Katz e Mutz (2019) busca dar legitimidade as propostas do Programa. 
DOI 10.33872/revcontrad.vlnl.e002 | v. 1, n. 1 | Jan./Jun. 2020

Para KATZ e MUTZ (2019) o mecanismo é entendido, no pensamento foucaultiano, como uma ferramenta de produção de saberes em função das demandas de poder de uma estratégia. A denúncia é o mecanismo da estratégia do Escola Sem Partido para colocar em ação técnicas educativo-políticas e jurídicas e, paralelamente, produzir saberes úteis a justificação das condutas das organizações (KATZ \& MUTZ, 2019). O intuito do ESP como citado anteriormente é combater uma suposta doutrinação ideológica, para tanto, é necessário que o Programa tenha "provas" concretas de que a mesma acontece dentro das Instituições de Ensino, é necessário legitimar a importância da implementação do Programa Escola Sem Partido, e este fim é alcançado por meio de denúncias, que ocorre através do site do Programa. O site fornece um passo a passo de como se fazer a denúncia, disponibiliza modelos de petições judiciais e ainda um tutorial para a gravação de uma aula.

Tal mecanismo oferece saberes que tornam verificáveis as afirmações da organização, de modo que ela possa advogar suas causas com o mínimo de fundamentação necessária para convencer ou, na pior das hipóteses, ameaçar os professores tidos como doutrinadores (KATZ \& MUTZ, 2019).

Uma outra forma de legitimação da existência do Programa Escola Sem Partido é dar voz à não-educadores. Com propostas que visam o cerceamento da liberdade de ensino, a criminalização do atuar docente e o esvaziamento da condição plural, laica e política do ensino é compreensível e principalmente confortante que os especialistas em Educação não cogitem a possibilidade de defender tais propostas elencadas pelo ESP. Por essas e outras, os atores responsáveis pelo Programa buscam em discursos dos mais diversos intelectuais liberais e conservadores (sobretudo), legitimar suas concepções.

Os autores Katz e Mutz (2019) trazem em seu artigo "Ciência, autoria e verdade nos ditos do Movimento Escola Sem Partido: o mecanismo da denúncia", uma lista de personalidades que apoiam o Movimento, alguns desses nomes são: Olavo de Carvalho (autointitulado filósofo, escritor, jornalista e conferencista), Janaína Conceição Paschoal (jurista e política brasileira), Reinaldo Azevedo (jornalista), Rodrigo Constantino (formado em economia) entre outros que estão divididos entre escritores, jornalistas, juristas e cientistas de diversas áreas.

Apesar do ESP forjar através deste mecanismo as bases que sustentam suas propostas, ele busca ao máximo sua legitimação através da formação acadêmica de seus porta-vozes. Mesmo tecendo duras críticas ao sistema educacional brasileiro, seus idealizadores sabem que precisam encontrar algum respaldo teórico no cientificismo empregado à nível acadêmico, e é 
DOI 10.33872/revcontrad.vlnl.e002 | v. 1, n. 1 | Jan./Jun. 2020

por essas e outras que é importante para o Movimento ter personalidades bem formadas e posicionadas socialmente do seu lado.

[...] para o Escola Sem Partido, não basta apenas criticar a doutrinação e dizer o verdadeiro num espaço selvagem, como explicamos há pouco. É preciso colar-se (mesmo que minimamente) a um campo de saber, a uma disciplina, requisitar uma legitimação dada por uma instituição universitária e, na sua ausência, no caso do ESP, se aproveitar do prestígio previamente consolidado por certo número de autores. Essa seria a etapa final do mecanismo da denúncia, iniciado com o incentivo de narrativas sobre a doutrinação, a convocação de alguns instauradores discursivos (os autores) e a construção de um conhecimento verdadeiro. Tudo isso, no fim das contas, para aproximar as enunciações do ESP dos discursos científicos reinantes de nossa época (KATZ \& MUTZ, p. 384, 2019).

O resultado da implementação do ESP na legislação educacional nacional seria a inspeção do trabalho docente, inspeção essa característica de governos autoritários. Corrêa e Ferri (2016) traz em seu artigo "Coordenação pedagógica: das influências históricas à ressignificação de uma nova prática", fatos históricos que detalham como se dava a inspeção docente em momentos históricos distintos. Durante o período de educação jesuítica, por exemplo, a educação religiosa era o foco principal do sistema educativo. Corrêa e Ferri (2016) diz que segundo Negrão (2000) os jesuítas zelavam para que a fidelidade doutrinária fosse mantida, para tanto, evitavam autores, questões polêmicas ou debates contrários à doutrina da igreja. O Ratio Studiorum era o material responsável por orientar os inspetores em seu trabalho de inspeção e supervisão. Corrêa e Ferri (2016) destacam que segundo Pinto (2011) uma das regras prescritas aos inspetores era

De quando em quando, ao menos uma vez ao mês, assista às aulas dos professores, leia também, por vezes, os apontamentos dos alunos. Se observar ou ouvir de outrem alguma coisa que mereça advertência, uma vez averiguada, chame a atenção do professor com delicadeza e afabilidade, e, se for mister, leve tudo ao conhecimento do Reitor (CORRÊA \& FERRI, 2016, p. 43).

Em um outro momento histórico Corrêa e Ferri (2016) retratam como se dava a existência da figura profissional do inspetor escolar, durante o governo de Getúlio Vargas, governo este que a partir do período denominado Estado Novo, passa a governar o país sob um regime ditatorial (autoritário). "Nesse momento a prática do inspetor era uma forma eficaz de controlar a qualidade da educação que se almejava na época, instituindo o poder da ideologia política dominante getulista sobre a prática educativa" (CORRÊA \& Ferri, p. 44, 2016). 
DOI 10.33872/revcontrad.vlnl.e002 | v. 1, n. 1 | Jan./Jun. 2020

Neste contexto, no período entre 1937 e 1945, a educação escolar sofreu intervenções do governo através da "inspeção escolar" da época, com a finalidade de eliminar qualquer foco de resistência à ideologia getulista. Assim, o projeto nacionalista nascia no "berço" da imposição, principalmente nas regiões de concentração de imigrantes italianos e alemães que se instalaram no sul do Brasil. As instituições construídas pelas comunidades locais, na concepção governista, eram uma ameaça à forma de controle exercida na época (FERREIRA \& FORTUNATO, 2010, p. 05).

Durante o regime militar que teve início no Brasil no ano de 1964 ocorreu também o cerceamento do trabalho pedagógico proposto pelo ESP. Durante as décadas de 60 e 70 investiu-se em formas mais eficazes de controle do atuar pedagógico, e na precarização da formação docente. O regime comprometeu-se com o desenvolvimento da industrialização do país, para tanto, seria necessário a formação de mão-de-obra rápida e qualificada. (FERREIRA \& FORTUNATO, 2010).

O estudo ofertado deveria focar exclusivamente em preparar a mão-de-obra operária, sem desenvolver nos educandos uma criticidade capaz de fazê-los contestar as decisões do governo militar. É neste contexto que surge os cursos técnicos profissionalizantes em nível médio.

Com um ensino focado no mercado de trabalho os responsáveis pela administração da educação nacional não consideravam necessário grande investimento em matérias que desenvolvesse senso crítico, ou seja, as ciências humanas não necessitavam de muita atenção (como ocorre em todos os governos autoritários). Surge por isso, a criação das licenciaturas curtas. Neste contexto temos a extinção dos cursos de História e Geografia, que foram reduzidas a habilitações dentro do curso de licenciatura plena em Estudos Sociais. Plazza e Priori (2014) diz que "a implantação de Estudos Sociais no lugar das Ciências Humanas, teve como um de seus objetivos despertar o civismo nos educandos, uma vez que seus conteúdos dariam prioridade principalmente aos "fatos históricos e heróis" brasileiros" (PLAZZA \& PRIORI, 2014, p. 10).

As licenciaturas curtas formariam profissionais da educação menos qualificados, pois seriam formados a toque de caixa para poderem suprir a necessidade de mão-de-obra, tornando-se dessa forma, meros proletários da educação, pois não teriam a formação necessária para serem autônomos frente às imposições governamentais. Visto ser o professor supostamente o detentor do saber, seria necessário atacar justamente sua formação, tirandolhe a capacidade de contestação, por isso foram criados os cursos de licenciatura curta através da Lei 5692/71 (PLAZZA \& PRIORI, 2014, p. 09). 
DOI 10.33872/revcontrad.vlnl.e002 | v. 1, n. 1 | Jan./Jun. 2020

As semelhanças com o modo de inspeção e cerceamento do atuar pedagógico sugeridas pelo ESP são gritantes, ao passo que os alunos são autorizados a fazer gravações das aulas e os professores tendem a ser punidos judicialmente pelos conteúdos dessas gravações.

Os professores conseguiram a muito custo com a redemocratização do país sua liberdade de ensinar. Neste contexto, o papel do supervisor/inspetor deixou de ser usado como forma de controle e cerceamento do trabalho docente e passou a ser um trabalho de ajuda mútua, de colaboração entre direção, orientação pedagógica e professores. É necessário o combate incansável a qualquer forma de restrição da liberdade (que nos remete a períodos imperiais e autoritários) de qualquer natureza, neste caso ainda mais delicado, quando se está em jogo o caráter laico, plural e democrático da escola, instituição responsável por formar de modo integral os indivíduos.

\section{Considerações finais}

Em síntese, o programa Escola Sem Partido busca através de uma linguagem carregada de neutralidade e totalmente simplista (no sentido superficial da palavra), legitimar a ideia de que a Educação que visa ao pleno desenvolvimento humano, tornando o aluno um indivíduo crítico, politizado e consciente ao invés de ideal, seja uma educação tendenciosa e doutrinária.

Analisando as propostas que traz o cartaz e principalmente o conteúdo explicito no site do movimento, é possível notar uma superficialidade no que diz respeito às concepções de ideologia e doutrinação consideradas pelo ESP. A linha que separa a exposição de conteúdo, levando em consideração a leitura de mundo, a análise crítica, as considerações e observações dos professores, e o que alguns consideram como doutrinação e imposição de ideologia é tênue.

Ressalta-se aqui a questão, onde termina a liberdade do professor em ensinar seus alunos levando em consideração, sua formação acadêmica e profissional, que o capacita e habilita para desempenhar tal função e onde começa a promoção de seus próprios interesses, opiniões, concepções ou preferências ideológicas a fim de gerar sobre o aluno um processo de inculcação e doutrinação ideológica? Apresentar um conteúdo em sala de aula de modo descritivo sem fazer apontamentos sobre as contradições e injustiças com relação ao mundo social, a escola se torna reprodutora da ordem vigente. Negando ao aluno as condições de 
DOI 10.33872/revcontrad.vlnl.e002 | v. 1, n. 1 | Jan./Jun. 2020

compreender os processos históricos e os interesses em conflito a escola ao invés de educar para a autonomia, cumpre um inegável papel conservador.

No que diz respeito a levar em consideração as convicções morais e religiosas de acordo com o que é preferido pela família, nos faz pensar em uma educação que ao invés de trabalhar o desenvolvimento da cidadania através da convivência e respeito pela diversidade e pluralidade de ideias e cultura, reforça o individualismo e a disseminação de preconceitos e intolerância a tudo que não está de acordo com o que o próprio indivíduo acredita. É compreensível que cada pessoa tenha seu ponto de vista, suas convicções políticas, religiosas, morais, e que a mesma seja respeitada apesar deles, no entanto, dentro do espaço escolar ou universitário que faz parte da dimensão e extensão social, suas próprias convicções ficam sujeitas ao respeito à diversidade e pluralidade presentes na sociedade. Aprender a conviver e respeitar os indivíduos, independentemente de suas particularidades faz parte do desenvolvimento da cidadania.

O papel da escola é trabalhar com a realidade social na qual estamos inseridos, o indivíduo tem todo o direito de não aceitar certas concepções e principalmente praticar a que lhe convém, no entanto, no convívio em sociedade suas próprias convicções e concepções ficam subordinadas ao bem-estar social de todos, e por isso mesmo é que nossa sociedade é considerada laica e plural, bases de uma sociedade democrática. Negar o bem-estar comum, negar a pluralidade e diversidade social é negar a cidadania.

No entanto, não é necessário grande esforço para percebermos o currículo oculto por trás do referido programa. Como dito anteriormente, uma educação descritiva, que não instigue a pensar, problematizar e questionar o meio social em que estamos inseridos, é uma educação que visa a perpetuação do status quo e a manutenção das relações sociais vigentes. A exemplo disso, temos os momentos históricos em que nosso país fora administrado por governos autoritários, e não coincidentemente adotaram medidas semelhantes aos ideais propostos pelo ESP.

Uma sociedade democrática deve opor-se veementemente a qualquer forma de censura e controle autoritário das liberdades (sejam elas de ensino, aprendizado, expressão, imprensa etc.). Uma Educação de qualidade deve garantir ao indivíduo sua emancipação e desenvolver no mesmo a cidadania, para tanto, o livre diálogo entre professor e aluno, o debate de ideias, e a capacidade de conviver e respeitar as diferenças devem ser condições primordiais.

\section{REFERÊNCIAS:}


DOI 10.33872/revcontrad.vlnl.e002 | v. 1, n. 1| Jan./Jun. 2020

BRASIL, Decreto $\mathbf{n}^{\circ}$ 3.321, de 30 de dezembro de 1999. Protocolo Adicional à Convenção Americana sobre Direitos Humanos em Matéria de Direitos Econômicos, Sociais e Culturais "Protocolo de São Salvador". São Salvador Nov./1988. Disponível em: <http://www.planalto.gov.br/ccivil_03/decreto/D3321.htm>. Acesso em: 06 de maio de 2020.

BRASIL, Projeto de lei n. ${ }^{\circ}$ 867, de 2015 - Câmara dos Deputados. Disponível em: https://www.camara.leg.br/proposicoesWeb/prop_mostrarintegra;jsessionid. Acesso em $06 \mathrm{de}$ maio de 2020.

CORRÊA, S. FERRI,C. Coordenação pedagógica: das influências históricas à ressignificação de uma nova prática. Revista Entreideias. Salvador, v. 05, n. 01, p. 41-56, 2016. Disponível em: <https://portalseer.ufba.br/index.php/entreideias/article/view/14994/10973>. Acesso em: 18 de Jun. de 2020.

FERREIRA, N. S. C. F.; FORTUNATO, S. A. de O. A inspeção escolar como forma de controle no estado novo: uma contribuição às origens da gestão da educação. Disponível em:http://www.sbhe.org.br/novo/congressos/cbhe4/individuais-

coautorais/eixo03/Naura\%20Syria\%20Carapeto\%20Ferreira\%20e\%20Sarita\%20Aparecida\% 20de\%20Oliveira.pdf Acesso em: 18 de Jun. de 2020.

FREIRE, P. Pedagogia da autonomia: saberes necessários à prática educativa. 25. ed. São Paulo: Paz e Terra, 1996.

MIGUEL, L. F. Da "doutrinação marxista" à "ideologia de gênero" - Escola Sem Partido e as leis da mordaça no parlamento brasileiro. Direito e Práxis. Rio de Janeiro, v. 07, n. 15, p. 590-621, 2016. Disponível em: 〈https://www.redalyc.org/pdf/3509/350947688019.pdf>. Acesso em: 31 de Mar. de 2020.

MUTZ, A. S. C. KATZ, E. P. Ciência, autoria e verdade nos ditos do movimento escola sem partido: O mecanismo da denúncia. Revista Estudos de Sociologia. Araraquara, v. 24, n. 47, p. 371-387, 2019. Disponível em: <https://periodicos.fclar.unesp.br/estudos/article/view/11039/8736>. Acesso em: 31 de Mar. de 2020 .

NICOLAZZI, F. Qual o partido da escola sem partido? Revista do Lhiste. Porto Alegre, v.03, n. $05, \quad$ p. 82-85, jul./dez./2016. Disponível em: $<$ https://scholar.googleusercontent.com/scholar?q=cache:FxwQFmzDbHAJ:scholar.google.co

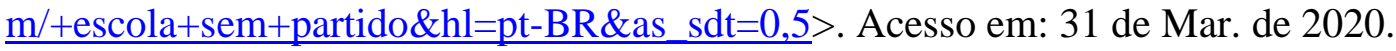

O professor da minha filha comparou Che Guevara a São Francisco de Assis. El País, São Paulo, 25 de jun. de 2016. Disponível em: <https://brasil.elpais.com/brasil/2016/06/23/politica/1466654550_367696.html>. Acesso em: 31 de Mar. de 2020.

PLAZZA, R.; PRIORI, A. O ensino de História durante a ditadura militar. Revista Dia a Dia Educação. $\quad$ P. $\quad 01-20, \quad 2014 . \quad$ Disponível $\quad$ em: $<$ http://www.gestaoescolar.diaadia.pr.gov.br/arquivos/File/producoes_pde/artigo_rosimary_pl azza.pdf $>$. Acesso em: 28 de Jul. de 2020. 
i Doutora em Educação (UEM). Professora adjunta da UNESPAR/Paranavaí). Email: cassiadiaspereira@yahoo.com.br

ii Acadêmica do curso de graduação em Pedagogia (UNESPAR/Paranavaí). Email:
thadvasconcelos@hotmail.com 